Canadian Journal of Higher Education Revue canadienne d'enseignement supérieur

Volume 42, No. 3, 2012, pages 65-92

\title{
Use of Campus Support Services by Ontario College Students
}

Peter Dietsche

University of Toronto

\begin{abstract}
Offering an array of support services to meet the diverse needs of post-secondary learners assumes that these services improve success by providing students with compensatory resources and opportunities for engagement (Purnell \& Blank, 2004). Little Canadian research, however, has examined students' use of support services. This study describes how campus support services are used by Ontario college students and factors that influence the uptake of those services. Results show that despite relatively high student-reported need, the majority of Ontario college students did not utilize most campus services. Age, gender and ethnicity, receptivity to support, negative college experiences, faculty referral, studying with peers, and poor grades were associated with increased use of some services. The findings argue for a proactive service delivery model using web-based resources to minimize location-based barriers and to more effectively promote services dedicated to student success.
\end{abstract}

\section{RÉSUMÉ}

Pour offrir un éventail de services de soutien permettant de répondre aux différents besoins des apprenants du postsecondaire, il faut assumer que ces services améliorent la réussite en offrant aux étudiants des ressources compensatoires et des possibilités d'engagement (Purnell \& Blank, 2004). Toutefois, peu de recherches canadiennes se sont penché l'utilisation des services de soutien par les étudiants. Cette étude décrit comment les étudiants des collèges de l'Ontario utilisent les services de soutien sur les campus et elle 
met en lumière les facteurs qui influencent leur participation. Les résultats montrent que, malgré le besoin relativement important mentionné par les étudiants, la majorité des étudiants des collèges de l'Ontario n'ont pas utilisé la plupart des services offerts sur les campus. Les conclusions suggèrent la nécessité de mettre en place un modèle de prestation de services proactif qui comprend des ressources en ligne pour surmonter les obstacles géographiques et mieux mettre à contribution les ressources institutionnelles consacrées à la réussite scolaire.

Community colleges in Canada and the U.S. have long provided access to higher education for those who would not otherwise be able or wish to attend university. For many, however, access to post-secondary education does not translate into graduation. Of firsttime students entering U.S. community colleges during the 1995-1996 school year, less than half earned a degree or certificate or transferred to a four-year institution within six years (Horn \& Nevill, 2006). Canadian data indicate that after five years, $15 \%$ of university students and $20 \%$ of community college students had not graduated (Finnie \& Qiu, 2009). Although higher educational attainment often translates into better job prospects and higher earnings, these benefits typically accrue to those who graduate, not just participate (Statistics Canada, 2004). Identifying effective strategies to improve student persistence, therefore, is of considerable interest to those who study and manage postsecondary institutions.

Many authors (Pascarella \& Terenzini, 1991; Thomas, 2002; Tinto, 1987) argue that in the current context of increased access to post-secondary education, student success requires integrating all learners into the social and academic fabric of the institution. Although many view this process as assimilative in that students must adapt to the institution (Bartram, 2009), others (Berger, 2000; Dietsche, 2005, 2009: Tierney, 2000) have argued for a model that champions the adaptation of institutions to the individual needs of students. Adaptive strategies typically focus on providing an array of campus support services such as personal and career counselling, services for students with disabilities, peer tutoring, academic advising, and centres for improving literacy and numeracy skills (Purnell \& Blank, 2004). Offering an array of support services to meet the varied needs of students assumes the services increase student success and persistence by providing them with additional resources that may be compensatory, thus helping disadvantaged students overcome their potential lack of information, cultural capital, or academic preparedness (Bailey \& Alfonso, 2005; Thomas, 2002). The theory is that if colleges provide enough structured opportunities for students to engage with institutional services, the students will be successful and persist at higher rates (Mechur-Karp, Hughes, \& O`Gara, 2008). Although it is clear that most post-secondary institutions make substantial investments in providing diverse campus services (Dietsche, 2005; Gilbert, Chapman, Dietsche, \& Grayson, 1997; Jenkins, 2007), little Canadian research has examined the use of those services by students in community colleges.

\section{LITERATURE REVIEW}

The need for campus support services in post-secondary institutions is clearly evident. For the past decade, government access policies have created increased student diversity 
on today's campuses. The Rae Report on Higher Education in Ontario (Rae, 2005), for example, recommended access for students traditionally under-represented in post-secondary education, such as Aboriginal youth, people with disabilities, first-generation students, immigrants, and students from low socio-economic backgrounds. Indeed, a study of three Ontario colleges (Malatest \& Associates, 2009) that assessed the incidence of three entering-student risk factors (low career clarity, socialization issues, and low writing scores) found "over one-third of students were identified as being at risk in two areas (37 percent), and 12 percent were at risk in all three areas" (Malatest \& Associates, 2009, p. 23).

Another source of evidence comes from the students themselves. Although the literature on student perceptions of their need for campus services is meagre at best, what does exist suggests the need is substantial. Boyd, Holder, Hunt, Hunt, Magoon, and Van Brunt (1999) found that over half of first- and second-year university students reported worries about getting good grades, procrastinating, studying effectively, feeling pressure over deadlines, managing time, preparing for exams, managing stress from overload, sleeping too little, remembering what they had read, and being nervous and tense. As well, Chandler and Gallagher (1996) listed anxiety and depression, and Stone and Archer (1990) and Stone, Vespia, and Kanz (2000) commented on the prevalence of eating disorders, alcohol abuse, and suicidality, along with increasing levels of violence and mental illness, among university students. A study of Canadian community college students (Human Resources and Social Development Canada [HRSDC], 2007) found that approximately one third of respondents reported their mathematics, time management, test-taking, and study skills were fair or poor. When asked whether they could benefit from extra support to succeed in their studies, two in five indicated they could benefit from help to improve their test-taking and study skills, and one quarter reported the same was true for their literacy and numeracy skills.

Bauman, Wang, DeLeon, Kafentzis, Zavala-Lopez, and Lindsey (2004) examined the likelihood of students using a variety of on-campus services and found that three quarters of respondents indicated they were likely or very likely to use career counselling services. Over half of the students indicated a likelihood of using stress management, financial aid, and time management workshops. Just under half said the same for study skills and personal counselling. Although these are indirect measures of need and are subject to the inaccuracies of student self-report, they do provide an estimate of the percentage of students who might seek help from campus support services.

There is also convincing evidence that early intervention for academically weak or unprepared students, through counselling or other support services, can improve persistence and academic performance (Fike \& Fike, 2008; Grubb, 2003). Summers (2003), in a review of the literature, found that counselling increases the retention of students who are identified as highly likely to drop out. Similarly, students with various personal problems reported their academic performance had improved as a direct result of the support services they received from a college counselling center (Turner \& Berry, 2000). Graham and Gisi (2000), using a large sample from the American College Testing Alumni Outcomes Survey, found that alumni satisfaction with academic advising, personal counselling, and other student services also increased alumni satisfaction with college and their reported learning outcomes. 


\section{Use of Campus Services}

Despite the substantial student-reported need for support from campus services and evidence for their effectiveness, research suggests that only a small proportion of students actually seek help (Clary \& Fristad, 1987; Kushner \& Sher, 1989; Upcraft, Gardner, \& Barefoot, 2005). A review by Raunic and Xenos (2008) found that at one British university only $3 \%$ of first-year students had used the university counselling service by the end of the second semester. Cooke, Bewick, Barkham, Bradley, and Audin (2006) reported that only $5 \%$ of students categorized as "vulnerable" on the basis of their psychological well-being scores had accessed university counselling. Similar overall utilization rates of between $2 \%$ and $4 \%$ have been reported in American (Yoo \& Skovholt, 2001), South African (Flisher, De Beer, \& Bokhorst, 2002), and Indonesian (Setiawan, 2006) university students. A survey of undergraduates in selected Canadian universities (Canadian University Survey Consortium, 2008) showed that only one in five utilized tutoring, career counselling, study skills workshops, learning support services, or personal counselling. The consensus is that not all students who experience problems or report they could benefit from support services seek help (Boyd et al., 1999; Oliver, Reed, Katz, \& Hugh, 1999). Why this is the case and what might be done to increase student use of campus services are key questions for additional research.

Research on factors that influence the use of campus services suggests the psychological and demographic characteristics of students are important. Students most likely to use counselling services, for example, are those experiencing some degree of psychological distress (Halgin, Weaver, Edell, \& Spencer, 1987) who lack adequate social support (Rickwood \& Braithwaite, 1994) and hold positive attitudes toward seeking help (Clary \& Fristad, 1987; Deane \& Todd, 1996; Kahn and Williams, 2003). Alexitch (2002) identified two types of student profiles associated with differential service use. One type, called the learning-oriented student, valued the process of learning, engaged in help-seeking strategies, and expressed a preference for an in-depth and process-oriented advising relationship. The second type, the grade-oriented student, valued a more outcomes-focused approach to education, felt threatened by seeking help, and was more likely to engage in non-adaptive or avoidant help-seeking strategies.

Studies on the influence of student demographic characteristics have shown that White students received more counselling than Black students (Herndon, Kaiser, \& Creamer, 1996; Sheu \& Sedlacek, 2004). Further, Asian Americans (Chin, 1998; Sue \& Sue, 2003), Latinos (McMiller \& Weisz, 1996), and people of colour (Diala, Muntaner, Walrath, Nickerson, LaVeist, \& Leaf, 2000; Leong, Wagner \& Tata, 1995) typically underutilize mental health services. The socio-economic background of students has also been found to be important. Mechur-Karp, O'Gara, and Hughes (2008) showed that support services were used most by those students who had the cultural and social resources to seek and take advantage of them. Students without cultural capital typically lack the social networks that could help them navigate college and were unlikely to have the cultural repertoires to approach faculty members for informal advising.

The research reviewed above is largely based on U.S. institutions and very little has focused on the use of campus services by Canadian community college students. The present study was designed to fill this gap by examining the perceived need for and use 
of support services by students in Ontario community colleges. Mainly, these colleges offer occupationally oriented one-year certificate or two- or three-year diploma programs, with most students enrolled full-time. The majority of programs are two or three years in length, with a much smaller number of four-year degree programs.

The data for this report were drawn from a larger study, the Ontario College Student Engagement Survey (OCSES), conducted in the academic years 2006 to 2008. The overall goals of this larger project were to obtain information on the characteristics of Ontario college students, their college experiences, and factors that influenced their success and persistence. The present report focuses on information from the OCSES project as it pertains to student needs for various campus services, the degree to which these services are used, and the key factors that influence their use.

\section{METHOD}

\section{Sample and Procedures}

In the fall of 2006, 2007, and 2008, all students enrolled in a post-secondary program approved by the Ontario Ministry of Training, Colleges and Universities and offered in the 24 Ontario community colleges were invited to participate in a survey. All of the colleges invited participation through posters, classroom announcements, student web portals, or targeted emails that provided a link to the survey site. Information from students was collected mid-November to mid-December of each academic year using a web-based survey hosted on a central server managed by the researchers. Students were asked to provide their unique, college-specific identification number to validate their college registration.

\section{Measures}

The survey instrument, a modified version of that employed by the author in earlier research (Dietsche, 1990; HRSDC, 2007), collected extensive information on the characteristics, college experiences, attitudes, behaviours, and perceptions of students and was identical in all three years of the project. The questionnaire examined student demographic characteristics, attitudes toward their studies, self-assessments of skills and abilities, difficulties with their studies, use of campus services, interactions with faculty and peers, perceptions of faculty instruction and of their institution, and participation in extracurricular activities. In addition, because students were asked to provide their college-specific student number when completing the questionnaire, a list of these unique identifiers was provided to each of the participating colleges. In February, each college provided the researchers with a file containing the overall first-term average, extracted from college administrative records, for those survey participants who in November had been registered in their first semester. Linking the survey data with performance information obtained from each college using the unique student identification number permitted an exploration of the relationship between academic performance and use of campus services for first-semester students.

The estimated need for support services was based on questionnaire items that assessed students' perceived ability in several skill areas, perceived benefit from extra support in these same skill areas, and their expressed likelihood of using the corresponding services. Ability level was measured by students' responses to the question "Using the scale 
below, how would you rate your

?” Responses for six skill areas (reading, writing, mathematics, test taking, study skills, and language comprehension) ranged from $1=$ poor to 4 = very good. Students' perceptions of the benefit they might gain from extra support in the same six academic skill areas as well as two areas of personal need (career guidance and disabilities) were measured by their response to the question "To what degree do you believe you could benefit from extra support in the areas below to be successful in your studies?" Responses ranged from $1=$ would be of no benefit to 4 = benefit greatly .

Students' receptivity to using a support service in the six academic skill and two personal need areas was assessed by the item "How likely would you be to accept support in the areas below to be successful in your program of studies?" Responses of $1=$ very unlikely to 4 = highly likely were possible. The frequency with which students made use of nine campus services corresponding to their perceived academic skill and personal support needs was measured by a continuous variable prompted by the question "Please indicate the number of times you used the college services listed below since beginning your studies here." Services in the list included disability services, math skills centre, language/writing centre, learning skills centre, personal counselling, peer tutoring, career counselling, academic advising, and the career resource centre.

Students' positive or negative attitudes toward their college studies were examined using several Likert items with responses ranging from $1=$ strongly disagree to $5=$ strongly agree. A positive attitude was reflected in the item "My studies are one of the most important things in my life," whereas negative attitudes were reflected in items such as "I may transfer into another program at the end of this semester," "I may quit my studies before I finish my program," and "I considered dropping out of my program at least once this semester." Additional Likert items such as "I am capable of getting a B+ average (78\%) or better in my courses" and "I have the ability to succeed in college-level studies" measured students' confidence in their ability to be successful.

Questionnaire items reflecting the college experience measured whether students were having difficulty with aspects of their studies including dealing with the workload, understanding the content of courses, knowing how to improve grades, knowing who to speak to about a problem, identifying a clear career direction, and balancing the demands of school, work, and family. Responses to the item "How difficult has each of the following been for you during your studies so far?" ranged from $\mathrm{O}=$ not difficult at all to $3=$ has been very difficult.

The degree to which students were socially integrated in their college was assessed by two measures of student-faculty interaction and peer-to-peer interaction. The first measure of student-faculty interaction was a continuous variable that asked students "How many times have you had face-to-face interactions with program faculty outside the classroom for ten minutes or more this semester." Two Likert items assessed the nature of this interaction by asking students to indicate their level of agreement with the statements "I have developed a good relationship with at least one faculty member" and "Faculty have referred me to other staff on campus." Responses to these items ranged from $1=$ strongly disagree to $5=$ strongly agree.

The frequency of interaction with peers was measured by a continuous variable that asked "On average, how many times per week do you study with one or more students?" Responses were aggregated into categories that ranged from never to 10 or more times per week. 


\section{Data Analysis}

The student information collected from the 2006, 2007, and 2008 November-December surveys was examined using frequency distributions, chi-square analyses, and Pearson correlation procedures of the Statistical Package for Social Sciences. Although the shortcomings of the chi-square statistic, especially with large samples, has been noted (Urdan, 2005), a conservative use can be effective in exploring differences between groups and associations between variables. The dataset comprising only full-time students for all three survey years consisted of 47,750 records, with almost two thirds of respondents enrolled in first semester, one fifth in their third term, and $4 \%$ in fifth semester. Very small percentages of students were enrolled in their second, fourth, and sixth semesters of study. This distribution is what would be expected for a fall survey, a time when the largest number of new students enrol in an Ontario community college; few do so in the winter or summer terms. The result is that the majority of fall semester students in Ontario colleges are in their first or third semester of study.

\section{RESULTS}

\section{Sample Profile}

A total of 24,735 students participated in the November-December survey in 2006, 19,989 in 2007 , and 17,710 in 2008 for a grand total of 62,434 full- and part-time students. The total enrolment in Ontario colleges was 155,303 in 2006, 164,604 in 2007, and 174,832 in 2008 (Colleges Ontario, 2008, 2009). The samples obtained by the Ontario College Student Engagement Survey, therefore, represented 16\% of system enrolment in $2006,12 \%$ in 2007 , and $10 \%$ in 2008 . An analysis of response rates by semester of study showed the decline in response rates over the three years was accounted for by decreased participation on the part of third- and fifth-semester students because these students were being surveyed repeatedly, up to two or three times. Nonetheless, Table 1 shows that the profile of the survey samples obtained each year on key demographic and program of study variables was highly stable. In addition, a comparison of the 2006-2008 OCSES survey sample profile with that of all Ontario college students on key demographic information (Colleges Ontario, 2008, 2009) confirmed that it was largely representative of the college student population. As shown in Table 2, however, female students and younger students were somewhat over-represented in the OCSES survey sample.

\section{Estimates of Need for Campus Services}

The analysis of survey items assessing need for services suggested a substantial need exists for Ontario college students. As measured by students' self-rating of ability, a significant number of respondents reported they could benefit from using campus services, assuming that a fair or poor level of ability in these areas would put their success at risk. Table 3 shows that math skills had the highest percentage (33\%) reporting a low level of ability, followed by study skills (31\%) and test-taking skills (21\%). Fewer students reported a fair or poor level of ability for writing (15\%), reading (10\%), and language comprehension (8\%). 
Table 1.

Sample Profile by Year

\begin{tabular}{|c|c|c|c|}
\hline Year & $2006(\%)$ & $2007(\%)$ & $2008(\%)$ \\
\hline \multicolumn{4}{|l|}{ Age } \\
\hline 19 or less & 31 & 32 & 34 \\
\hline $20-24$ & 46 & 44 & 43 \\
\hline $25-29$ & 10 & 10 & 10 \\
\hline $30-39$ & 7 & 7 & 7 \\
\hline 40 or more & 3 & 4 & 4 \\
\hline \multicolumn{4}{|l|}{ Gender } \\
\hline Female & 62 & 62 & 63 \\
\hline Male & 37 & 37 & 36 \\
\hline \multicolumn{4}{|l|}{ First Language } \\
\hline English & 81 & 81 & 80 \\
\hline French & 4 & 4 & 6 \\
\hline Other & 15 & 15 & 13 \\
\hline \multicolumn{4}{|l|}{ Program Duration } \\
\hline Less than one year & 2 & 2 & 2 \\
\hline One year & 11 & 11 & 12 \\
\hline 2 years & 46 & 47 & 48 \\
\hline 3 years & 32 & 31 & 29 \\
\hline 4 years & 8 & 7 & 7 \\
\hline
\end{tabular}

Table 2.

OCSES Sample Profile versus Ontario College System

\begin{tabular}{lcc}
\hline Source & OCSES (\%) & Ontario Colleges (\%) \\
\hline Age & & \\
$\quad$ less than 21 & 49 & 44 \\
$21-25$ & 33 & 38 \\
$26-30$ & 8 & 8 \\
31-35 & 4 & 4 \\
$\quad$ more than 35 & 6 & 6 \\
Gender & & \\
$\quad$ Female & 60 & 54 \\
$\quad$ Male & 40 & 46 \\
First Language & & \\
$\quad$ English & 80 & 79 \\
$\quad$ French & 4 & 15 \\
$\quad$ Other & 15 & 11 \\
Sub-Group & & 10 \\
$\quad$ Students with a disability & 10 & 5 \\
$\quad$ Students with dependants & 13 & \\
\hline
\end{tabular}


Table 3.

Ontario College Students' Ratings of Proficiency in Skill Areas

\begin{tabular}{lccc}
\hline & \multicolumn{3}{c}{ Self Rating of Proficiency (\%) } \\
\cline { 2 - 4 } Skill Area & Very Good & Good & Fair + Poor \\
\hline Math & 28 & 40 & 33 \\
Study & 20 & 50 & 31 \\
Test taking & 31 & 49 & 21 \\
Writing & 38 & 47 & 15 \\
Reading & 48 & 42 & 10 \\
Language comprehension & 55 & 37 & 8 \\
\hline
\end{tabular}

Similar results were obtained when students reported the degree to which they could benefit from extra support in the same academic skill areas, as well as career guidance, in order to be successful in their studies. Table 4 shows that approximately one third indicated they could benefit greatly from additional support in the areas of study skills, test taking, and career guidance. One quarter indicated they could benefit greatly by improving their math skills. As with self-ratings of ability level, fewer students reported they could benefit from help to improve their writing skills (17\%), reading skills (17\%), and language comprehension (12\%).

Table 4 .

Perceived Benefit of Extra Support by Service Area

\begin{tabular}{lcc}
\hline Service Area & Benefit Somewhat (\%) & Benefit Greatly (\%) \\
\hline Study skills & 41 & 35 \\
Test-taking skills & 39 & 32 \\
Career guidance & 33 & 30 \\
Math skills & 34 & 25 \\
Writing skills & 43 & 17 \\
Reading skills & 34 & 17 \\
Language comprehension & 23 & 12 \\
Disability services & 12 & 9 \\
\hline
\end{tabular}

\section{Use of Campus Services}

In spite of the relatively high student-reported need to improve literacy, numeracy, and learning skills, Table 5 shows that, based on self-report, the majority of Ontario college students did not use the corresponding campus services designed to address these 
needs. For students registered in any of six semesters, usage rates ranged from a high of $30 \%$ for the career resource centre and academic advising to a low of $10 \%$ for disability services. Career counselling, peer tutoring, and personal counselling were utilized by approximately $20 \%$ of respondents and services to improve literacy, numeracy, and learning skills were used by approximately $15 \%$ of the survey sample.

Table 5 .

Degree of Non-Use by Service Area

\begin{tabular}{lc}
\hline Service Area & Non-Use (\%) \\
\hline Disability services & 90 \\
Math skills & 87 \\
Language/writing & 85 \\
Learning skills & 85 \\
Personal counselling & 83 \\
Peer tutoring & 83 \\
Career counselling & 79 \\
Academic advising & 70 \\
Career resource centre & 70 \\
\hline
\end{tabular}

An analysis of the frequency of campus service use by students over the six semesters represented in the survey sample showed little change for most areas. Many of the services showed consistently low levels (15\%) of use from the first to the sixth semester. Academic advising and the career resource centre, however, exhibited a modest increase in use by students over time. The career resource centre, in particular, exhibited an increase in use from $26 \%$ of first-semester students to $45 \%$ of those in their sixth semester. Other services targeting literacy, numeracy, and learning skills showed little increase from the first to the sixth semester.

\section{Perceived Benefit and Likelihood of Service Acceptance}

Items on the questionnaire permitted an examination of the degree to which students' self-perceived need for skill development in a specific area influenced their expressed likelihood of accepting help from the corresponding service. The Pearson correlation coefficients between perceived benefit from extra support and likelihood of accepting such help if it were offered are shown in Table 6. Although significant correlations $(p<.01$, twotailed, $n=43,273$ ) were observed, they were of a moderate magnitude. In other words, some students who reported they could benefit from extra support to develop a specific skill also said they would not likely use the service if it were offered. The highest coefficients were observed for the diagonals of the correlation matrix; students were most likely to indicate a likelihood of accepting help in a specific area if they also perceived they could benefit from extra support in the same area. The highest benefit-likelihood correlations were seen in the areas of disabilities (.768) and improving comprehension in the language of instruction (.761). Not surprisingly, perceived benefit from support in reading, writing, 
and language comprehension skills and the likelihood of accepting help in these areas were also correlated with each other. Perceived benefit from extra support developing test-taking skills was also significantly correlated with a likelihood of accepting help with study (.598), reading (.437), and writing (.404) skills.

Table 6.

Perceived Need and Service Receptivity

\begin{tabular}{lcccccccc}
\hline & \multicolumn{7}{c}{ Likelihood of Accepting Help With } \\
\cline { 2 - 8 } $\begin{array}{l}\text { Benefit from extra } \\
\text { support with }\end{array}$ & $\begin{array}{c}\text { Writing } \\
\text { skills }\end{array}$ & $\begin{array}{c}\text { Reading } \\
\text { skills }\end{array}$ & $\begin{array}{c}\text { Math } \\
\text { skills }\end{array}$ & $\begin{array}{c}\text { Study } \\
\text { skills }\end{array}$ & $\begin{array}{c}\text { Test-taking } \\
\text { skills }\end{array}$ & $\begin{array}{c}\text { Selecting } \\
\text { a career }\end{array}$ & Disability & $\begin{array}{c}\text { Comprehend } \\
\text { language }\end{array}$ \\
\hline Writing skills & $.662^{*}$ & $.533^{*}$ & $.320^{*}$ & $.392^{*}$ & $.398^{*}$ & $.284^{*}$ & $.240^{*}$ & $.403^{*}$ \\
Reading skills & $.545^{*}$ & $.682^{*}$ & $.362^{*}$ & $.433^{*}$ & $.444^{*}$ & $.298^{*}$ & $.305^{*}$ & $.473^{*}$ \\
Math skills & $.302^{*}$ & $.341^{*}$ & $.692^{*}$ & $.335^{*}$ & $.345^{*}$ & $.235^{*}$ & $.189^{*}$ & $.267^{*}$ \\
Study skills & $.366^{*}$ & $.395^{*}$ & $.323^{*}$ & $.649^{*}$ & $.547^{*}$ & $.252^{*}$ & $.174^{*}$ & $.276^{*}$ \\
Test taking skills & $.404^{*}$ & $.437^{*}$ & $.371^{*}$ & $.598^{*}$ & $.687^{*}$ & $.249^{*}$ & $.206^{*}$ & $.305^{*}$ \\
$\begin{array}{l}\text { Selecting a } \\
\text { career }\end{array}$ & $.276^{*}$ & $.296^{*}$ & $.246^{*}$ & $.264^{*}$ & $.265^{*}$ & $.683^{*}$ & $.161^{*}$ & $.287^{*}$ \\
Disability & $.265^{*}$ & $.318^{*}$ & $.222^{*}$ & $.218^{*}$ & $.233^{*}$ & $.180^{*}$ & $.768^{*}$ & $.355^{*}$ \\
$\begin{array}{l}\text { Comprehend } \\
\text { language }\end{array}$ & $.437^{*}$ & $.486^{*}$ & $.308^{*}$ & $.321^{*}$ & $.333^{*}$ & $.297^{*}$ & $.362^{*}$ & $.761^{*}$ \\
\hline
\end{tabular}

Note. ${ }^{*}$ Correlation is significant at the .01 level (two-tailed) $(n=43,273)$.

\section{Influences on Service Use}

Student responses to the survey were examined to identify factors associated with variation in the use of academic advising, personal, and career counselling, services to develop literacy, numeracy, and learning skills, and peer tutoring. The analyses examined variables shown in the literature to influence service use. These variables included demographic and background characteristics, attitudes regarding skills and personal development needs and the use of campus services, attitudes toward and difficulties with their college studies, and interaction with faculty and peers. The role of academic achievement, measured by first-term final average, in influencing campus service use for first-semester students was also examined using information drawn from college administrative records.

\section{Demographic and background characteristics.}

Chi-square analyses identified relatively weak but significant differences in the use of campus services as a function of age, gender, first language, Aboriginal ancestry, visible minority status, and disability status. Age was found to have a relatively weak association with the use of services in that those 40 years or older used personal counselling $\left(\chi^{2}(8, n\right.$ $=38,008)=253.4, p<.000, \gamma=.131)$ and peer tutoring $\left(\chi^{2}(8, n=37,872)=428.2, p<\right.$ $.000, \gamma=.165)$ to a greater degree than those 19 years or younger. 
Gender appeared to have little influence on service use except for personal counselling, where females were more frequent clients $\left(\chi^{2}(2, n=39,358)=116.9, p<.000, \gamma=\right.$ -.147), and math services, where the opposite was true $\left(\chi^{2}(2, n=39,358)=256.71, p<\right.$ $.000, \gamma=.209$ ).

A first language other than English or French was related to increased use of career counselling $\left(\chi^{2}(4, n=38,765)=283.13, p<.000, \gamma=.202\right)$, language/writing services $\left(\chi^{2}(4, n=\right.$ $38,906)=889.82, p<.000, \gamma=.365)$, learning skills services $\left(\chi^{2}(4, n=38,869)=398.62, p\right.$ $<.000, \gamma=.269)$, and peer tutoring services $\left(\chi^{2}(4, n=39,006)=409.86, p<.000, \gamma=.251\right)$. No significant differences were observed for personal counselling or math services.

Students who reported Aboriginal ancestry used personal counselling $\left(\chi^{2}(2, n=\right.$ $39,342)=189.94, p<.000, \gamma=.247)$, language $/$ writing centre $\left(\chi^{2}(2, n=39,153)=119.08\right.$, $p<.000, \gamma=.191)$, and learning skills centre $\left(\chi^{2}(2, n=39,145)=108.27, p<.000, \gamma=\right.$ $.176)$ to a greater degree than non-Aboriginal students. Students who declared a visible minority status exhibited increased use of language/writing services $\left(\chi^{2}(2, n=34,440)\right.$ $=394.2, p<.000, \gamma=.278)$ and learning skills services $\left(\chi^{2}(2, n=34,398)=201.32, p<\right.$ $.000, \gamma=.199)$ as well as peer tutoring $\left(\chi^{2}(2, n=34,526)=240.9, p<.000, \gamma=.200\right)$. Finally, students with a disability utilized all campus support services examined, except math skills services, to a greater degree than those who did not report a disability.

\section{Receptivity to support.}

Previous research has shown that students who have positive attitudes about using campus services are more likely to use services (Clary \& Fristad, 1987; Deane \& Todd, 1996; Kahn and Williams, 2003). In this study, Pearson correlations between students' expressed likelihood of accepting support for academic and personal needs and their frequency of using the corresponding services were calculated to determine whether similar results would be obtained with Ontario college students. Although only weak to modest coefficients were found, the pattern of associations was as expected. For example, Table 7 shows that the correlation between students' expressed likelihood of accepting help for a specific skill or personal need was consistently higher for the campus service that corresponded to the same area. Those who indicated they were receptive to support in developing their math skills were most likely to have used the math skills service and less likely to have used personal counselling. The highest correlation observed (.418) was between receptivity to support for a disability and use of disability services, though an elevated likelihood of accepting help for a disability was also associated with use of personal counselling $(r=.221)$ and learning skills services $(r=.240)$.

\section{Attitudes toward college studies.}

A number of Likert items on the questionnaire examined positive and negative attitudes held by students toward their college studies. Chi-square analyses to determine whether specific attitudes were associated with an increased use of specific campus services supported this expectation, as shown in Table 8. Students who reported a positive view of their studies by strongly agreeing with "My studies are one of the most important things in my life" used academic advising more frequently $\left(\chi^{2}(8, n=39,660)=222.8, p\right.$ $<.000, \gamma=.122)$ than those who disagreed with the statement. An increased use of many 
Table 7.

Service Receptivity and Service Use

\begin{tabular}{|c|c|c|c|c|c|c|c|c|c|}
\hline \multirow[b]{2}{*}{$\begin{array}{l}\text { Likely to } \\
\text { accept help } \\
\text { with }\end{array}$} & \multicolumn{9}{|c|}{ Service Used } \\
\hline & $\begin{array}{l}\text { Academic } \\
\text { advising }\end{array}$ & $\begin{array}{l}\text { Personal } \\
\text { counsel- } \\
\text { ling }\end{array}$ & $\begin{array}{l}\text { Career } \\
\text { counsel- } \\
\text { ling }\end{array}$ & $\begin{array}{l}\text { Language/ } \\
\text { writing } \\
\text { service }\end{array}$ & $\begin{array}{l}\text { Learning } \\
\text { skills } \\
\text { service }\end{array}$ & $\begin{array}{l}\text { Math } \\
\text { skills } \\
\text { service }\end{array}$ & $\begin{array}{l}\text { Peer } \\
\text { tutoring }\end{array}$ & $\begin{array}{l}\text { Career } \\
\text { resource } \\
\text { centre }\end{array}$ & $\begin{array}{l}\text { Disability } \\
\text { services }\end{array}$ \\
\hline $\begin{array}{l}\text { Writing } \\
\text { skills }\end{array}$ & $.138^{*}$ & $.112^{*}$ & $.126^{*}$ & $.211^{*}$ & $.185^{*}$ & $.095^{*}$ & $.105^{*}$ & $.097^{*}$ & $.107^{*}$ \\
\hline $\begin{array}{l}\text { Reading } \\
\text { skills }\end{array}$ & $.144^{*}$ & $.121^{*}$ & $.141^{*}$ & $.223^{*}$ & $.213^{*}$ & $.119^{*}$ & $.122^{*}$ & $.106^{*}$ & $.124^{*}$ \\
\hline Math skills & $.117^{*}$ & $.083^{*}$ & $.111^{*}$ & $.126^{*}$ & $.155^{*}$ & $.242^{*}$ & $.121^{*}$ & $.110^{*}$ & $.075^{*}$ \\
\hline $\begin{array}{l}\text { Study } \\
\text { skills }\end{array}$ & $.128^{*}$ & $.109^{*}$ & $.099^{*}$ & $.131^{*}$ & $.163^{*}$ & $.108 *$ & $.089^{*}$ & $.083^{*}$ & $.089^{*}$ \\
\hline $\begin{array}{l}\text { Test- } \\
\text { taking } \\
\text { skills }\end{array}$ & $.129^{*}$ & $.109^{*}$ & $.105^{*}$ & $.136^{*}$ & $.169^{*}$ & $.117^{*}$ & $.097^{*}$ & $.088^{*}$ & $.097^{*}$ \\
\hline $\begin{array}{l}\text { Selecting a } \\
\text { career }\end{array}$ & $.094^{*}$ & $.058^{*}$ & $.125^{*}$ & $.091^{*}$ & $.089^{*}$ & $.067^{*}$ & $.042^{*}$ & $.114^{*}$ & $.023^{*}$ \\
\hline Disability & $.187^{*}$ & $.221^{*}$ & $.150^{*}$ & $.191^{*}$ & $.240^{*}$ & $.115^{*}$ & $.127^{*}$ & $.057^{*}$ & $.418^{*}$ \\
\hline $\begin{array}{l}\text { Com- } \\
\text { prehend } \\
\text { language }\end{array}$ & $.122 *$ & $.108 *$ & $.137^{*}$ & $.226^{*}$ & $.205^{*}$ & $.113^{*}$ & $.119^{*}$ & $.106^{*}$ & $.095^{*}$ \\
\hline
\end{tabular}

Note. ${ }^{*}$ Correlation is significant at the .01 level (two-tailed) $(n=43,273)$.

services, however, was observed for students with attitudes suggesting they were unhappy with their program of study. For example, an increased use of academic advising $\left(\chi^{2}(8\right.$, $n=39,643)=284.4, p<.000, \gamma=.120)$, personal counselling $\left(\chi^{2}(8, n=39,371)=195.8\right.$, $p<.000, \gamma=.123)$, career counselling $\left(\chi^{2}(8, n=38,983)=390.2, p<.000, \gamma=.168\right)$, the language/writing centre $\left(\chi^{2}(8, n=39,125)=207.4, p<.000, \gamma=.148\right)$, and math centre $\left(\chi^{2}(8, n=39,293)=245.0, p<.000, \gamma=.173\right)$ was observed for students who strongly agreed with the statement "I may transfer into another program at the end of this semester." Those who strongly agreed with "I may quit my studies before I finish my program" were more frequent users of personal counselling $\left(\chi^{2}(8, n=39,370)=233.8, p<.000, \gamma\right.$ $=.143)$, the language/writing centre $\left(\chi^{2}(8, n=39,125)=244.6, p<.000, \gamma=.142\right)$, and the math centre $\left(\chi^{2}(8, n=39,294)=135.1, p<.000, \gamma=.126\right)$. Finally, personal counselling was accessed more often by those who agreed with "I considered dropping out of my program at least once this semester" $\left(\chi^{2}(8, n=39,013)=381.5, p<.000, \gamma=.182\right)$. The findings suggested that the clients of many campus services, both services that develop academic skills and services that help students deal with the stress of college studies, are learners who are encountering academic difficulties and are dissatisfied with their program of study. 
Table 8.

Attitudes and Service Use

\begin{tabular}{lcccc}
\hline & \multicolumn{4}{c}{ Attitude Toward College Studies } \\
\cline { 2 - 5 } Service Area & $\begin{array}{c}\text { My studies } \\
\text { are important }\end{array}$ & $\begin{array}{c}\text { I may transfer } \\
\text { into another } \\
\text { program }\end{array}$ & $\begin{array}{c}\text { I may quit } \\
\text { my studies before } \\
\text { I finish }\end{array}$ & $\begin{array}{c}\text { I considered } \\
\text { dropping out at } \\
\text { least once }\end{array}$ \\
\hline Academic advising & $\checkmark$ & $\checkmark$ & $\checkmark$ & $\checkmark$ \\
Personal counselling & $\checkmark$ & $\checkmark$ & \\
Career counselling & $\checkmark$ & $\checkmark$ & \\
Language/writing & $\checkmark$ & & \\
Learning skills & $\checkmark$ & & \\
Math centre & & & \\
Peer tutoring & & & & \\
\hline
\end{tabular}

Note. $\checkmark=$ used service more frequently

Further insight into the relationship between student attitudes and campus service use was found by examining questionnaire items that reflected students' confidence in their ability to succeed. The analyses showed that those more likely to disagree with "I am capable of getting a $\mathrm{B}+$ average $(78 \%)$ or better in my courses" were more frequent users of the math centre $\left(\chi^{2}(8, n=39,263)=193.0, p<.000, \gamma=.168\right)$, the learning skills centre $\left(\chi^{2}\right.$ $(8, n=39,057)=208.9, p<.000, \gamma=.158)$, and personal counselling $\left(\chi^{2}(8, n=39,336)=\right.$ $151.4, p<.000, \gamma=.114)$. Similarly, students who more frequently used the math centre $\left(\chi^{2}\right.$ $(8, n=38,941)=135.1, p<.000, \gamma=.142)$ and learning skills services $\left(\chi^{2}(8, n=38,729)=\right.$ $110.2, p<.000, \gamma=.107)$ were more likely to disagree with the statement "I have the ability to succeed in college-level studies." The overall portrait derived from an examination of student attitudes toward their studies suggested that those who make use of campus support services are less likely to view their program of study positively and are less confident about their ability to succeed but view their studies as an important part of their life.

\section{Difficulties with college.}

Research on student stress and help-seeking behaviour (Kahn \& Williams, 2003) has found that service use is associated with higher levels of stress. Several questionnaire items acted as a proxy for stress by measuring the degree of difficulty students reported they had with academic and personal aspects of their college studies. The overall results of chi-square analyses are shown in Table 9. Three findings are notable. First, consistent with the literature on student stress and service use, those who reported a high level of difficulty in each area were more likely to use campus support services. Second, different types of difficulties were associated with the use of specific services. For example, those students who cited having great difficulty with "Identifying a clear career direction/path" used career counselling $\left(\chi^{2}(6, n=38,952)=372.5, p<.000, \gamma=.185\right)$ and academic advising services $\left(\chi^{2}(6, n=39,612)=207.3, p<.000, \gamma=.112\right)$ more frequently than those 
not reporting this difficulty. The career counselling service was used exclusively by those having difficulty with a career plan; those encountering other academic and personal difficulties did not exhibit a heightened use of this specific service.

Table 9.

Service Use by Type of Difficulty

\begin{tabular}{|c|c|c|c|c|c|c|c|c|c|}
\hline \multirow[b]{2}{*}{ Service Area } & \multicolumn{9}{|c|}{ Type of Difficulty with College } \\
\hline & $\begin{array}{l}\text { Program } \\
\text { workload }\end{array}$ & $\begin{array}{l}\text { Work } \\
\text { and } \\
\text { study }\end{array}$ & $\begin{array}{c}\text { Balance } \\
\text { demands }\end{array}$ & $\begin{array}{l}\text { Course } \\
\text { content }\end{array}$ & $\begin{array}{l}\text { Improve } \\
\text { grades }\end{array}$ & $\begin{array}{l}\text { Identify } \\
\text { a career }\end{array}$ & $\begin{array}{l}\text { Who } \\
\text { to talk } \\
\text { to }\end{array}$ & $\begin{array}{l}\text { Know } \\
\text { how I'm } \\
\text { doing }\end{array}$ & $\begin{array}{l}\text { Teaching } \\
\text { methods }\end{array}$ \\
\hline Academic advising & $\checkmark$ & & $\checkmark$ & $\checkmark$ & $\checkmark$ & $\checkmark$ & & & \\
\hline Personal counselling & $\checkmark$ & $\checkmark$ & $\checkmark$ & $\checkmark$ & $\checkmark$ & & $\checkmark$ & $\checkmark$ & $\checkmark$ \\
\hline Career counselling & & & & & & $\checkmark$ & & & \\
\hline Language/writing & & & & $\checkmark$ & $\checkmark$ & & $\checkmark$ & & \\
\hline Learning skills & $\checkmark$ & & & $\checkmark$ & $\checkmark$ & & & & $\checkmark$ \\
\hline Math centre & & & & $\checkmark$ & $\checkmark$ & & & & $\checkmark$ \\
\hline Peer tutoring & & & & $\checkmark$ & $\checkmark$ & & & & $\checkmark$ \\
\hline
\end{tabular}

Note. $\checkmark=$ used service more frequently

In addition to having difficulty identifying a career plan, those who most frequently used academic advising services also reported they were having difficulty with "Dealing with the program workload" (number of assignments, course load, class time) ( $\chi^{2}(6, n=$ $39,776)=225.2, p<.000, \gamma=.119)$, "The content of college courses" $\left(\chi^{2}(6, n=39,587)\right.$ $=248.3, p<.000, \gamma=.125)$, "Knowing how to improve my grades in courses I'm having trouble with" $\left(\chi^{2}(6, n=39,691)=264.9, p<.000, \gamma=.124\right)$, and "Balancing the demands of school and family" $\left(\chi^{2}(6, n=39,500)=307.8, p<.000, \gamma=.133\right)$.

Personal counselling was the most extensively used service of those examined, with students who reported experiencing difficulties in all areas, except identifying a clear career path, making use of this service. Students who reported difficulty with "Dealing with the program workload" $\left(\chi^{2}(6, \mathrm{n}=39,501)=574.6, p<.000, \gamma=.234\right)$, "The content of college courses" $\left(\chi^{2}(6, n=39,314)=504.8, p<.000, \gamma=.219\right)$, "Knowing how to improve my grades in courses I'm having trouble with" $\left(\chi^{2}(6, n=39,414)=478.3, p<.000, \gamma=.207\right)$, "Knowing who to talk to when I have a problem" $\left(\chi^{2}(6, n=39,405)=318.7, p<.000, \gamma=\right.$ .168), "Knowing how well I'm doing in my courses" $\left(\chi^{2}(6, n=39,393)=227.8, p<.000, \gamma\right.$ $=.151)$, and "The methods used by faculty to teach" $\left(\chi^{2}(6, n=39,425)=312.7, p<.000, \gamma=\right.$ .165) were more likely to use personal counselling than those not reporting these difficulties.

The language/writing centre, math centre, learning skills service, and peer tutoring services were found to be most frequently used by students who were having difficulty with course content, grade improvement, and teaching methods. In addition, the language/writing centre was used by students who reported having difficulty with "Knowing how to improve my grades in courses I'm having trouble with" $\left(\chi^{2}(6, n=39,159)=197.8\right.$, $p<.000, \gamma=.154)$. 
The final notable finding is that although students who reported high levels of difficulty with multiple aspects of their studies used support services more frequently, large percentages of these groups (65\% to $75 \%$ depending on the service area) still did not use the relevant service.

\section{Interaction with faculty and peers.}

Tinto $(1975,1987)$ has argued that success depends on integrating students into an institution academically and socially. The questionnaire used in this study contained quantitative measures of student-faculty interaction and peer-to-peer interaction as measures of the degree to which students were integrated socially.

The chi-square analysis of frequency of faculty interaction and students' use of services showed that as the frequency of interaction with faculty outside the classroom increased, students made use of all the campus support services examined in this study more often. A higher level of student-faculty interaction was associated with increased use of academic advising $\left(\chi^{2}(8, n=37,967)=155.9, p<.000, \gamma=.321\right)$, personal counselling $\left(\chi^{2}(8, n=37,705)=747.0, p<.000, \gamma=.285\right)$, career counselling $\left(\chi^{2}(8, n=37,349)=\right.$ 853.0, $p<.000, \gamma=.281)$, language/writing services $\left(\chi^{2}(8, n=37,476)=528.3, p<.000\right.$, $\gamma=.253)$, learning skills services $\left(\chi^{2}(8, n=37,436)=669.8, p<.000, \gamma=.286\right)$, the math centre $\left(\chi^{2}(8, n=37,647)=421.4, p<.000, \gamma=.226\right)$, and peer tutoring services $\left(\chi^{2}(8, n\right.$ $=37,582)=727.9, p<.000, \gamma=.280$ ). These results show the power of student-faculty interaction: those students who have frequent contact with faculty are more likely to use campus services.

Examining student responses to items assessing the nature of the student-faculty interaction showed that having a good relationship with faculty had less impact on service use than did faculty referral. Analysis of "I have developed a good relationship with at least one faculty member" showed a modest increase in the use of two services only, academic advising $\left(\chi^{2}(8, n=38,078)=515.0, p<.000, \gamma=.180\right)$ and personal counselling $\left(\chi^{2}(8, n=37,815)=279.1, p<.000, \gamma=.171\right)$, for students who strongly agreed with this statement. However, the analysis of "Faculty have referred me to other staff on campus" and frequency of service use showed faculty referral had a significant impact on the use of all services examined except for the math centre. Students who strongly indicated the faculty they met with referred them to other staff on campus exhibited greater use of academic advising $\left(\chi^{2}(8, n=38,052)=1410.0, p<.000, \gamma=.266\right)$, personal counselling $\left(\chi^{2}(8, n=37,788)=803.0, p<.000, \gamma=.244\right)$, career counselling $\left(\chi^{2}(8, n=37,432)=\right.$ $803.8, p<.000, \gamma=.248)$, language $/$ writing services $\left(\chi^{2}(8, n=37,559)=447.2, p<.000\right.$, $\gamma=.208)$, learning skills services $\left(\chi^{2}(8, n=37,521)=533.2, p<.000, \gamma=.224\right)$, and peer tutoring $\left(\chi^{2}(8, n=37,669)=461.8, p<.000, \gamma=.191\right)$.

The results related to frequency of out-of-class interaction with faculty were ambiguous because students who used campus services might be more likely to interact with faculty. However, the analysis of the item "I have developed a good relationship with at least one faculty member," likely also associated with frequent contact with faculty, suggested that the referral by faculty was the important driver of service use. Students who indicated faculty actively referred them to campus services exhibited higher levels of use. In the case of academic advising, only $19 \%$ of those who strongly disagreed with "Faculty have referred me to other staff on campus" used advising services, whereas $43 \%$ of those 
who strongly agreed reported they used the service. The implication is that students who interact with faculty are more likely to be referred to campus services and in turn use many campus services more frequently.

Interaction with peers is also an important component of being socially integrated in college. The degree to which students interacted with their peers was measured in this study with the continuous variable questionnaire item "On average, how many times per week do you study with one or more students?” Responses were aggregated into categories that ranged from never to 10 or more times per week. As with faculty referral, analyses showed an increased use of all services examined, except for personal counselling, as the frequency of students' studying with their peers increased. The impact was particularly significant in the case of peer tutoring services $\left(\chi^{2}(8, n=30,353)=682.8, p<.000\right.$, $\gamma=.281)$ and math skills services $\left(\chi^{2}(8, n=30,412)=438.4, p<.000, \gamma=.250\right)$. In the first instance, $28 \%$ of students who reported they studied with peers 10 or more times a week had used peer tutoring services one or more times compared to $9 \%$ of students who said they never studied with their peers. In the case of the math centre, only $7 \%$ of students who never studied with peers had used the service compared to $20 \%$ of those who studied with their peers 10 or more times. The results suggest that programs or initiatives designed to increase peer interaction could be an effective strategy to increase the use of most campus support services.

\section{Term average and service use.}

Some research (Schwitzer, 2005) has suggested that low-achieving students do not generally use campus support services. This study examined the relationship between term final average obtained from college administrative records and the frequency of support service use. Because grade information was available for first-semester students only, the sample size for the analyses varied from 25,306 to 24,936 depending on the service area examined. Although gamma coefficients resulting from chi-square analyses of first-term average and frequency of use for the seven services examined were not large, it was found that as final average declined, use of some services increased. A significant difference between high- and low-achieving students was observed for the use of personal counselling $\left(\chi^{2}(10, n=25,150)=229.2, p<.000, \gamma=-.182\right)$, the learning skills centre $\left(\chi^{2}(10, n=\right.$ $24,969)=212.6, p<.000, \gamma=-.187)$, and the math centre $\left(\chi^{2}(10, n=25,113)=282.6, p<\right.$ $.000, \gamma=-.229)$. However, the difference between high- and low-performing students in use/non-use of services was often low. For example, $89 \%$ of those who achieved a term final average of $90 \%$ or more did not use personal counselling services compared to $77 \%$ of those who obtained an average of $50 \%$ or less. Overall, the results suggested that a larger number of poorly performing students do take advantage of campus support services as compared with those who are doing well, but the differences are not great.

\section{DISCUSSION}

This study is the first to examine the use of campus support services by students in Ontario colleges. The research goals were to estimate the need for various services, describe the degree to which these services were used by students, and identify the factors, both student and institutional, that influenced service use. 


\section{Student Need and Service Use}

The magnitude of need for campus support services was estimated in this study in two ways: students' self-ratings of proficiency in various academic skill areas and their assessment of the degree to which they could benefit from extra support in these same areas. Both measures provided estimates that one third to one quarter of Ontario college students could benefit from campus support services to develop their math skills and learning skills (for example, study habits and test taking). One third also reported they could benefit from support in identifying a career. The results are consistent with an Ontario report (Malatest \& Associates, 2008) on one college's post-admission literacy testing that found almost half (47\%) of incoming native English-speaking students scored below the cut-off for entry into a college-level English course. Research on college-bound Ontario high school students (King, Warren, Boyer, \& Chin, 2005; King \& Warren, 2006) also suggested a substantial need for remediation in this group as one quarter obtained an English mark of between 50\% and 60\% in their final year and one third obtained the same result in their math course. The available evidence suggests that a substantial need for campus support services exists in the Ontario student population.

The findings for service use, however, indicate that about one half of the students who reported a support need in a particular area actually made use of the corresponding service. Moreover, the use academic skills development services such as the language skills centre and learning skills centre did not increase with semester of study, suggesting that the first semester may be critical in determining the use of services. Career services, an exception, showed increased use as students neared graduation, showing that, for some areas at least, as students perceive a need, their service use increases. However, as has been pointed out previously (Dietsche, 1999), a "need-use gap" exists between students and support services in Ontario colleges.

\section{Influences on Service Use}

A key focus of this study was to understand the factors that influence service use. Factors examined included demographic variables, attitudes, sources of stress (including difficulties with studies), social interaction with faculty and peers, and academic achievement.

\section{Demographics.}

Consistent with the research (Herndon, Kaiser, \& Creamer, 1996; Sheu \& Sedlacek, 2004) highlighting the influence of demographic factors on service use, this study found differential patterns of service use depending on the factor examined. Contrary to the findings on the impact of race and ethnicity from U.S. research, the current study found that Aboriginal and visible minority status increased the use of academic advising, literacy, and learning skills services. Age had an impact in that older students made more frequent use of personal counselling and peer tutoring. The creation of the college-based Second Career program (Government of Ontario, 2008) targeting out-of-work mature learners is a possible source of this finding because older students entering college for the first time bring a variety of issues such as childcare and anxieties about their ability to succeed (Newman, 1995). More women were clients of personal counselling, whereas more men used math services. Finally, a first language other than English was associated 
with increased use of academic advising, career counselling, and literacy and numeracy skills services. The observed patterns of service use likely reflect the specific needs of each group. For example, math-intensive technology programs in Ontario colleges are male dominated and therefore contribute to increased use of math services by men.

\section{Attitudes.}

Positive attitudes toward seeking help have been shown to influence service use (Clary \& Fristad, 1987; Deane \& Todd, 1996). Two types were examined in this study: attitudes toward the use of campus services and attitudes toward their college studies. In the first case, the findings show that students who believed they could benefit from extra support to improve a specific skill were more likely to be receptive to the support and that this receptivity was associated with increased service use. Although this finding is consistent with those of others (Clary \& Fristad, 1987; Deane \& Todd, 1996; Kahn \& Williams, 2003), the relationship between receptivity and use was modest at best and many who were receptive did not use services. Because the data for this study were collected late in the fall semester, it is unlikely that the difference is due to an unrealistic perception of need by students: by that time, they would be well aware of the academic demands. Perhaps other barriers such as a lack of information about existing services or anxiety about their use are responsible for students not acting on their positive view of help seeking.

Most research on student attitudes and service use has focused on those related to help-seeking behaviour. This study has expanded this area by examining attitudes that reflect the college experience. The results show that attitudes reflecting a negative experience increased the use of specific services. Specifically, students who disliked their program of study or were contemplating dropping out or transferring to another program exhibited an increased use of services such as career and personal counselling, academic advising, and literacy and numeracy centres. Similarly, those who had doubts about their ability to succeed in their studies were more likely to use personal counselling and learning and literacy skills services.

\section{Difficulty with studies.}

Students most likely to use counselling services are those experiencing some degree of psychological distress (Halgin, Weaver, Edell, \& Spencer, 1987). In this study, psychologically distressed students were defined as those reporting a high degree of difficulty with various academic and personal aspects of their studies. Two findings are of note. First, higher levels of reported difficulty were associated with a higher frequency of service use, confirming the impact of student distress suggested by previous research. Second, specific types of difficulties were found to be associated with specific patterns of service use. Generally, students used advising and personal counselling more frequently if they were struggling with personal difficulties such as handling the workload, finding someone to speak with about a problem, identifying a clear career plan, and managing the multiple demands of work, school, and family.

The language, math, and learning skills services and peer tutoring were most frequently used by students experiencing academic difficulties in such areas as course content, grade improvement, and teaching methods. Students having difficulty identifying a clear 
career direction exhibited an increased use of academic advising and career counselling. Overall, the findings show that although the level of service use exhibited by students was quite low, the pattern of use is what one would expect. Students sought out the services that corresponded well with their specific difficulties and consequent need for support. Although those experiencing a high level of stress/difficulty did make more frequent use of services, the level of use was still very low, even among this group.

\section{Interaction with faculty and peers.}

In addition to the foregoing evidence for the impact of student characteristics on service use, this study also provided some evidence for important institutional influences. The findings, like those of Pascarella and Terenzini (1991), show that frequency of student-faculty contact, positive student-faculty relationships, and faculty referral of students to other campus staff increased the use of all campus services examined. Peers were also shown to have a key, but slightly different, impact: students who studied frequently with peers also made more frequent use of academic skills services such as peer tutoring and language and learning skills services. As has been argued by others (Kuh, 1995), the results suggest that institutions could influence the use of campus services by implementing policies to promote student-faculty interaction, encourage faculty referral, and peerto-peer interaction, especially through study groups.

\section{Achievement.}

Some research (Schwitzer, 2005) has shown campus services tend to attract developmentally higher-functioning, lower-risk participants rather than the developmentally fragile, higher-risk learners who are the main intended audience. This study, however, found that students with lower grades made more frequent use of the math centre, learning skills services, and personal counselling. The psychological distress engendered by low grades likely served as an incentive to seek support from campus services. Once again, however, only a minority of students in the low-performing group sought help. Three in four of this group did not do so.

\section{CONCLUSIONS AND IMPLICATIONS FOR PRACTICE}

The results of this study generally support previous research and suggest a number of conclusions. First, based on self-report, the case may be made that a substantial number of Ontario college students could benefit from accessing campus support services. Although the use of these services is influenced by student demographic characteristics, receptivity toward service use, negative experiences of college, and poor academic performance, the overall level of use is low. Some students make a judicious use of the services that correspond to their specific needs, but many fail to do so. The important question is why.

Barriers to the use of campus services can be of two types: student and institutional. Student-related barriers to the utilization of counselling services include perceived selfsufficiency, denial as a coping style, unwillingness to discuss personal problems, lack of knowledge about counselling services, not knowing what to ask, and the perception of stigma related to receiving counselling (Grubb, 1996; Komiya, Good, \& Sherrod, 2000; Surf \& Lynch, 1999). Having family or friends who can help and a belief in their ability to 
solve their own problems have also been reported as barriers (Setiawan, 2006). Finally, psychological factors also contribute to student avoidance of help-seeking, including social stigma, treatment fears, fear of emotion, anticipated utility and risks, self-disclosure, social norms, and self-esteem (Vogel, Wester, \& Larson, 2007). The infrequent use of services found in this study, however, is unlikely to be due to perceived self-sufficiency or denial because many students reported they needed extra support.

So, what might be done to increase the use of campus services by Ontario college students? Study findings suggest that a new service delivery model is necessary to remove key institutional barriers. Karp, Hughes, and O'Gara (2008) argue that disadvantaged students may benefit from what Grubb (2006) and others term intrusive advising. Rosenbaum, Deil-Amen, and Person (2006) note that the passive delivery model assumes that students have enough knowledge, social skills, and motivation to seek out and make use of available services. Rather than passive delivery or a "build it and they will come" approach (Dietsche, 1999, 2009), intrusive advising includes structured meetings with advisers, mandatory activities such as academic planning, and close tracking of student success (Heisserer \& Parette, 2002; Mechur-Karp, 2011). Indeed, the effectiveness of the intrusive advising delivery model using the caseworker approach has already been shown to be effective with Ontario college students (Malatest \& Associates, 2009).

A proactive model that includes an online component could minimize many of the barriers associated with a lack of time for commuter students, lack of knowledge about services, stigma, and not knowing what to ask (Hornak, Akweks \& Jeffs, 2010), especially for those services of a less confidential nature. The use of web-based communication strategies that enhance a two-way exchange of information in real time could potentially provide more efficient service. Academic advising, for example, could provide a wide range of online services to students, including e-mail advising and adviser chat rooms that allow either live or asynchronous discussions of student questions (Hornak, Akweks, \& Jeffs, 2010; Shea, 2005).

Another conclusion of this study is additional support for the already well documented impact of student interaction with faculty and peers (Braxton, Hirschy, \& McClendon, 2004; Cabrera, Nora, \& Castañeda, 1993; Pascarella \& Terenzini, 1991). More frequent classroom interaction between students and faculty that emphasizes the value of campus services could increase their use, not only by highlighting the availability of services, but also by altering attitudes toward their use (Merchur-Karp, 2011). This approach is particularly appropriate for commuter students because most of their time on campus is spent in the classroom (Pascarella \& Terenzini, 1991). Noting that students rate advice provided by faculty as extremely useful (Alexitch \& Page, 1997) and that it has a positive effect on their learning, Alexitch (2002) and others (Pearson \& Bowman, 2000; Romer \& Whipple, 1991) suggested that personal invitations to an advising session by faculty could encourage students to develop more proactive and adaptive help-seeking strategies. In addition, the influence of peers on attitudes toward service use (Astin, 1993; Kuh, 1995; RingerLepre, 2007) suggests that explicit policies to promote student-student interaction could increase the use of campus services by changing students' attitudes toward help seeking.

The challenge for those providing campus support services in Ontario colleges, therefore, is to reach tech savvy and time-pressed students on their own terms. An emerging model that draws on student information from online assessments to create student-specific intrusive advising information delivered via the web (Dietsche, 2007, 2009) could 
remove key barriers. Simply eliminating the logistical difficulties and uncertainties of face-to-face contact with campus service staff could mean students will have their questions answered and problems solved via online tutorials or a chat with a counsellor. Ultimately, these experiences could translate into the success and retention of students who would have otherwise failed and dropped out.

\section{Limitations}

This study is characterized by a number of limitations that are principally related to the survey sample. Because the sample was one of convenience and constituted between $10 \%$ and $16 \%$ of the population over three years, it is possible that the sample is not completely representative of the entire Ontario college student population. In addition, although the profile of the OCSES sample closely parallels that of Ontario college students, the fact that women and younger students were somewhat overrepresented may have skewed the results. These concerns are balanced, however, by the large number of students who participated in the surveys.*

\section{REFERENCES}

Alexitch, L. R. (2002). The role of help-seeking attitudes and tendencies in students' preferences for academic advising. Journal of College Student Development, 43(1), 5-19.

Alexitch, L. R., \& Page, S. (1997). Evaluation of academic and career counseling information and its relation to student educational orientation. Canadian Journal of Counselling, 31, 205-218.

Astin, A. W. (1993). What matters in college: Four critical years: Revisited. San Francisco, CA: Jossey-Bass.

Bailey, T., \& Alfonso, M. (2005). Paths to persistence: An analysis of research on program effectiveness at community colleges. Indianapolis, IN: Lumina Foundation for Education.

Bartram, B. (2009). Student support in higher education: Understandings, implications and challenges. Higher Education Quarterly, 63(3), 308-314.

Bauman, S., Wang, N., DeLeon, C., Kafentzis, J., Zavala-Lopez, M., \& Lindsey, M. (2004). Nontraditional students' service needs and social support resources: A pilot study. Journal of College Counseling, 7, 13-17.

Berger, J. B. (2000). Optimising capital, social reproduction, and undergraduate persistence: A sociological perspective. In J. M. Braxton (Ed.), Reworking the student departure puzzle (pp. 95-126). Nashville, TN: Vanderbilt University Press.

Boyd, V., Holder, V., Hunt, P., Hunt, S., Magoon, T., \& Van Brunt, J. (1999). Issues of concern to undergraduate students: Do students seek help for these concerns? (Counseling Center Research Report 19). College Park, MA: University of Maryland.

Braxton, J. M., Hirschy, A. S., \& McClendon, S. A. (2004). Understanding and reducing college student departure. San Francisco, CA: Jossey-Bass .

Cabrera, A. F., Nora, A., \& Castañeda, M. B. (1993). College persistence: Structural equations modeling test of an integrated model of student retention. Journal of Higher Education, 64(2), 123-139. 
Canadian University Survey Consortium. (2008). Undergraduate student survey 2008: Master report. Retrieved from www.cusc-ccreu.ca/publications.htm

Chandler, L. A., \& Gallagher, R. P. (1996). Developing a taxonomy for problems seen at a university counseling center. Measurement and Evaluation in Counseling and Development, 29, 4-12.

Chin, J. L. (1998). Mental health services and treatment. In L. C. Lee \& N. W. Zane(Eds.), Handbook of Asian American psychology (pp. 485-504). Thousand Oaks, CA: Sage.

Clary, E. G., \& Fristad, M. A. (1987). Predictors of psychological help seeking on a college campus. Journal of College Student Personnel, 28, 180-181.

Colleges Ontario. (2008). 2008 Environmental scan: Student and graduate profiles. Retrieved from www.collegesontario.org/research/2008_environmental_scan.html

Colleges Ontario. (2009). 2009 Environmental scan: Student and graduate profiles. Retrieved from www.collegesontario.org/research/2009_environmental_scan.html

Cooke, R., Bewick, B. M., Barkham, M., Bradley, M., \& Audin, K. (2006). Measuring, monitoring, and managing the psychological well-being of first year university students. British Journal of Guidance \& Counselling, 34, 505-517.

Deane, F. P., \& Todd, D. M. (1996). Attitudes and intentions to seek professional psychological help for personal problems or suicidal thinking. Journal of College Student Psychotherapy, 10(4), 45-59.

Diala, C., Muntaner, C., Walrath, C., Nickerson, N. J., LaVeist, T. A., \& Leaf, P. J. (2000). Racial differences in attitudes toward professional mental health care and in the use of services. American Journal of Orthopsychiatry, 70, 455-464.

Dietsche, P. (1990). Freshman attrition in a college of applied arts and technology of Ontario. Canadian Journal of Higher Education, 20(3). 65-84.

Dietsche, P. (1999). Student needs and college services: Can we make the match? Communique, Journal of the Canadian Association of College and University Student Services. 3, 14-27.

Dietsche, P. (2005). Exemplary practices in college learning: Results of the PanCanadian survey of colleges. Montreal, QC: Canada Millennium Scholarship Foundation.

Dietsche, P. (2007). Deconstructing student departure: Lessons from research on community college students. Student Success, The Newsletter for Higher Education Professionals (pp. 4-5). Virginia Beach, VA: Educational Policy Institute.

Dietsche, P. (2009). Small steps to a big idea: Personalizing the post-secondary experience. In B. Leibowitz, A. Van Der Merwe, \& S. Van Schalkwyk (Eds.), Focus on first-year success: Perspectives emerging from South Africa and beyond (pp. 37-46). Stellenbosch, South Africa: Sun Media.

Fike, D., \& Fike, R. (2008). Predictors of first-year student retention. Community College Review, 36(2), 68-88. 
Finnie, R., \& Qiu, T. (2009). Is the glass (or classroom) half empty or nearly full? New evidence on persistence in post-secondary education in Canada. In R. Finnie, R. Mueller, A. Sweetman, \& A. Usher (Eds.) Who goes, who stays, what matters: Access to and remaining in post-secondary education in Canada (pp. 179-207). Montreal, QC, \& Kingston, ON: McGill-Queen's University Press \& School of Policy Studies.

Flisher, A. J., De Beer, J. P., \& Bokhorst, F. (2002). Characteristics of students receiving counselling services at the University of Cape Town, South Africa. British Journal of Guidance \& Counselling, 30, 299-310.

Gilbert, S., Chapman, J., Dietsche, P., \& Grayson, P. (1997). From best intentions to best practices: The first-year experience in Canadian post-secondary education (Monograph 22). Columbia, SC: National Resource Center for the Freshman Year Experience.

Government of Ontario. (2008). 2008 Ontario budget. Retrieved from www.fin.gov. on.ca/en/budget/ontariobudgets/2008

Graham, S. W., \& Gisi, S. L. (2000). The effects of instructional climate and student affairs services on college outcomes and satisfaction. Journal of College Student Development, 41(3), 279-292.

Grubb, W. N. (1996). Working in the middle: Strengthening education and training for the midskilled labor force. San Francisco, CA: Jossey-Bass.

Grubb, W. N. (2003). Using community colleges to reconnect disconnected youth. Menlo Park, CA: William and Flora Hewlett Foundation.

Grubb, W. N. (2006). "Like, what do I do now?”: The dilemmas of guidance counseling. In T. Bailey \& V. S. Morest (Eds.), Defending the community college equity agenda (pp. 195-222). Baltimore, MD: Johns Hopkins University Press.

Halgin, R. P., Weaver, D. D., Edell, W. S., \& Spencer, P. G. (1987). Relation of depression and help-seeking history to attitudes toward seeking professional psychological help. Journal of Counseling Psychology, 34, 177-185.

Heisserer, D., \& Parette, P. (2002). Advising at-risk students in college and university settings. College Student Journal, 36(1), 69-83.

Herndon, J., Kaiser, J., \& Creamer, D. (1996). Student preferences for advising styles in community college environments. Journal of College Student Development, 37(6), 637-648.

Horn, L., \& Nevill, S. (2006). Profile of undergraduates in U.S. post-secondary education institutions 2003-04: With a special analysis of community college students (NCES 2006-184). Washington, DC: National Center for Education Statistics.

Hornak, A. M., Akweks, K., \& Jeffs, M. (2010). Online student services at the community college. New Directions for Community Colleges, 150, 79-87.

Human Resources and Social Development Canada [HRSDC]. (2007). Pan-Canadian study of first-year college students-Report 1 student characteristics and the college experience. Gatineau, QC: Author. 
Jenkins, D. (2007). Institutional effectiveness and student success: A study of highand low-impact community colleges. Community College Journal of Research and Practice, 31, 945-962.

Kahn, J. H., \& Williams, M. N. (2003). The impact of prior counseling on predictors of college counseling center use. Journal of College Counseling, 6, 144-154.

King, A .J.C., \& Warren, W. K. (2006). Transition to college: Perspectives of secondary school students. Toronto, ON: Association of Colleges of Applied Arts and Technology of Ontario.

King, A. J. C., Warren, W. K., Boyer, J.C., \& Chin, P. (2005). Double cohort study: Phase 4 report. Toronto, ON: Ontario Ministry of Education.

Komiya, N., Good, G. E., \& Sherrod, N. B. (2000). Emotional openness as a predictor of college students' attitudes toward seeking psychological help. Journal of Counseling Psychology, 47, 138-143.

Kuh, G. D. (1995). The other curriculum: Out-of-class experiences associated with student learning and personal development. Journal of Higher Education, 66, 123-155.

Kushner, M. G., \& Sher, K. J. (1989). Fear of psychological treatment and its relation to mental health service avoidance. Professional Psychology: Research and Practice, 2O, 251-257.

Leong, F. T. L., Wagner, N. S., \& Tata, S. P. (1995). Racial and ethnic variations in helpseeking attitudes. In J. G. Ponterotto, J. M. Casas, L. A. Susuki, \& C. M. Alexander (Eds.), The handbook of multicultural counseling (pp. 415-438). Thousand Oaks, CA: Sage.

Malatest, R.A., \& Associates. (2008). Early implementation report: Evaluation of foundations for success pilot project. Montreal, QC: Canada Millennium Scholarship Foundation.

Malatest, R.A., \& Associates. (2009). Final impacts report: Foundations for success project. Montreal, QC: Canada Millennium Scholarship Foundation.

McMiller, W. P., \& Weisz, J. R. (1996). Help-seeking preceding mental health clinic intake among African-American, Latino, and Caucasian youths. Journal of the American Academy of Child and Adolescent Psychiatry, 35, 1086-1094.

Mechur-Karp, M. (2011). Toward a new understanding of non-academic student support: Four mechanisms encouraging positive student outcomes in the community college (CCRC Working Paper No. 28). New York, NY: Teachers College, Columbia University.

Mechur-Karp, M., Hughes, K., \& O‘Gara, L. (2008). An exploration of Tinto’s integration framework for community college students. New York, NY: Teachers College, Community College Research Center, Columbia University.

Mechur-Karp, M., O’Gara, \& Hughes. (2008). Do support services at community colleges encourage success or reproduce disadvantage? An exploratory study of students in two community colleges. New York, NY: Teachers College, Columbia University.

Newman, B. K. (1995). Career change for those over 40: Critical issues and insights. Career Development Quarterly, 44(1), 64-66. 
Oliver, J. M., Reed, C. K. A., Katz, B. M., \& Hugh, J. A. (1999). Students' self-reports of help-seeking: The impact of psychological problems, stress and demographic variables on utilization of formal and informal support. Social Behavior and Personality, 27(2), 109-128.

Pascarella, E., \& Terenzini, P. (1991). How college affects students: Findings and insights from twenty years of research. San Francisco, CA: Jossey-Bass.

Pearson, F., \& Bowman, R. (2000). The faculty role: Implications for collaboration with student affairs. College Student Affairs Journal, 19(2), 29-40.

Purnell, R., \& Blank, S. (2004). Support success: Services that may help low-income students succeed in community college. New York, NY: MDRC.

Rae, B. (2005). Ontario: A leader in learning. Toronto, ON: Queen's Printer for Ontario.

Raunic, A., \& Xenos, S. (2008). University counselling service utilisation by local and international students and user characteristics: A review. International Journal of Counselling, 30, 262-267.

Rickwood, D. J., \& Braithwaite, V. A. (1994). Social-psychological factors affecting help-seeking for emotional problems. Social Science Medicine, 39, 563-572.

Ringer-Lepre, C. (2007). Getting through to them: Reaching students who need career counseling. Career Development Quarterly, 56, 74-84.

Romer, K. T., \& Whipple, W. (1991). Collaboration across the power line. College Teaching, 39(2), 66-70.

Rosenbaum, J., Deil-Amen, R., \& Person, A. (2006). After admission: From college access to college success. New York, NY: Russell Sage Foundation.

Schwitzer, A. M. (2005). Self-development, social support, and student help-seeking. Journal of College Student Psychotherapy, 20(2), 29-52.

Setiawan, J. L. (2006). Willingness to seek counselling, and factors that facilitate and inhibit the seeking of counselling in Indonesian undergraduate students. British Journal of Guidance \& Counselling, 34, 403-419.

Shea, P. (2005). Serving students online: Enhancing their learning experience. New Directions for Community Colleges, 112, 15-24.

Sheu, H., \& Sedlacek, W. (2004). An exploratory study of help-seeking attitudes and coping strategies among college students by race and gender. Measurement and Evaluation in Counseling and Development, 37, 130-143.

Statistics Canada. (2004). Canadian labour market at a glance. Retrieved from www. statcan.ca/english/freepub/71-222-XIE/200400o/chart-f37.htm

Stone, G. L., \& Archer, J. A. (1990). College and university counseling centers in the 1990s: Challenges and limits. Counseling Psychologist, 18, 539-607.

Stone, G. L., Vespia, K. M., \& Kanz, J. E. (2000). How good is mental health care on college campuses? Journal of Counseling Psychology, 47, 498-510. 
Sue, D. W., \& Sue, D. (2003). Counseling the culturally diverse: Theory and practice (4th ed.). New York, NY: Wiley.

Summers, M. D. (2003). ERIC Review: Attrition research at community colleges. Community College Review, 3o(4), 64-84.

Surf, A. L., \& Lynch, G. (1999). Exploring young people's perceptions relevant to counselling: A qualitative study. British Journal of Guidance \& Counselling, 27, 231-243.

Thomas, E. (2002). Student retention in higher education: The role of institutional habitus. Journal of Education Policy, 17(4), 423-32.

Tierney, W.G. (2000). Power, identity and the dilemma of college student departure. In J. Braxton (Ed.), Reworking the student departure puzzle (pp. 213-234). Nashville, TN: Vanderbilt University Press.

Tinto, V. (1975). Dropout from higher education: A theoretical synthesis of recent research. Review of Educational Research, 45, 89-125.

Tinto, V. (1987). Leaving college: Rethinking the causes and cures of student attrition. Chicago, IL: University of Chicago Press.

Turner, A.L., \& Berry, T.R. (2000). Counseling center contributions to student retention and graduation: A longitudinal assessment. Journal of College Student Development, 41, 627-63.

Upcraft, M. L., Gardner, J. N., \& Barefoot, B. O. (2005). Challenging and supporting the first-year student: A handbook for improving the first year of college. San Francisco, CA: Jossey-Bass.

Urdan, T. C. (2005). Statistics in plain English (2nd ed.). London, England: Lawrence Erlbaum.

Vogel, D., Wester, L. M., \& Larson, S. R. (2007). Avoidance of counselling: Psychological factors that inhibit seeking help. Journal of Counseling and Development, 85, 410-422.

Yoo, S. K., \& Skovholt, T. M. (2001). Cross-cultural examination of depression expression and help-seeking behavior: A comparative study of American and Korean college students. Journal of College Counseling, 4, 10-19.

\section{CONTACT INFORMATION}

Peter Dietsche

Department of Theory and Policy Studies in Education

University of Toronto

252 Bloor St. West

Toronto ON M5S 1V6 Canada

Peter.Dietsche@utoronto.ca

Peter Dietsche is Assistant Professor of Higher Education in the Department of Theory and Policy Studies in Education at the Ontario Institute for Studies in Education/University of Toronto and holds the William G. Davis Chair in Community College Leadership. For three decades his research has focused on the impact of policy and practice on student 
educational outcomes in Canadian and U.S. community colleges. Projects include the Pan-Canadian Study of College Students and the College Experience, the Pan-Canadian Survey of Exemplary Practices in College Learning, the Ontario College Student Engagement Surveys, and the Ontario College Counselling Services Survey. 